\title{
論文特集 $\left\lceil\mathrm{C}_{1}\right.$ の化学」
}

（日本化学会誌，1982，（2）, p. 242２48）

(C) 1982 The Chemical Society of Japan

\section{ロジウムカルボニル触媒を用いたエチレン共存下における アセチレン類のカルボニル化反応 一- 5-エチル-2(5H)-フラノンの合成 ${ }^{1)}$}

(1981 年 7 月 2 日受 理)

\author{
洪 邦 夫*·三瀬 孝也・山崎 博 史
}

$\mathrm{Rh}_{4}(\mathrm{CO})_{12}$ を触媒として, トリェチルアミン中でジフェニルアセチレン $[4 \mathrm{a}]$ をカルボニル化 (CO $\left.30 \mathrm{~kg} / \mathrm{cm}^{2}, 220^{\circ} \mathrm{C}\right)$ すると，5-エチリデン-3,4-ジフェニル-2(5H)-フラノン〔5]が5\% 収率で得られ た。ここでェチレンを共存させると，〔5]の還元体である 5-エチル-3, 4-ジフェニル-2(5H)-フラノン [6 a $](16 \%)$ が得られた。反応溶媒どしてアルコール類や含水アセトンを用いると[6 a $]$ の収率がい らじるしく向上した $(73 \%)$ 。2-ブチン $[4 \mathrm{~b}]$ や1-フェニルプロピン [4 c $]$ も同様に反応し，3,4-二置 換 5-エチル-2 $(5 H)$-フラノンを与えた。〔4 c の場合には高い位置選択性が認められた。触媒として, 種々のロジゥム錯体や塩類も有効であるが， $\mathrm{Rh}_{4}(\mathrm{CO})_{12}$ や $\mathrm{Rh}_{6}(\mathrm{CO})_{16}$ の活性が高かった。エタノール 中での反応では相当量のアセトアルデヒド=ジェチル=ア.セタールとジェチルトンが生成した。 $125^{\circ} \mathrm{C}$ 前後の反応温度では, これら副生成物は減少するが, エタノールが反応に直接関与した 5-エトキシ 3 , 4-ジフェニル-2(5H)-フラノン〔15]と3-(エトキシカルボニル)-2-フェニル-1-インダノン [16]が副 生した。

\section{1 楮言}

均一系触媒によるアセチレン類のカルボニル化は,アクリル酸, コハク酸, ヒドロキノン, ラクトンならびに環状ケトンなど，有 用な化合物を一段の反応で与えるので，有機合成化学的に重要な

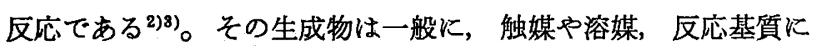
より大きく左右される。たとえば，アクリル酸やュハク酸のエス テルはアルコール中でのアセチレンのカルボニル化により合成さ れ, $\left.\mathrm{Ni}(\mathrm{CO})_{4}{ }^{4}\right)$ や $\mathrm{Co}_{2}(\mathrm{CO})_{8}{ }^{5}$ が触媒としてそれぞれ用いられる。 ここでパラジウム錯体を触媒とするとフマル酸やマレイン酸のエ

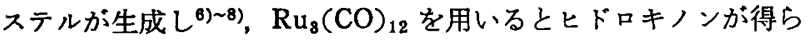

理化学研究所, 351 和光市広沢

1）この報文を“ロジウム触媒による不飽和化合物のカルボニ ル化反応関する研究(第 1 報)”とする。

2) P. Pino, G. Braca, "Organic Syntheses via Metal Carbonyls", ed. by I. Wender, P. Pino, Wiley, New York (1977) Vol.2, p. 419.

3) A. Mullen, "New Syntheses with Carbon Monoxide", ed. by J. Falbe, Springer-Verlag, Berlin (1980) p. 243.

4) W. Reppe, Ann., 582, 1(1953).

5) G. Natta, G. Albanesi, Chim. Ind.(Milan), 48, 1157 (1966).

6) G. P. Chiusoli, C. Venturello, S. Merzoni, Chem. Ind. (London), 1968, 977.

7) J. Tsuji, M. Morikawa, S. Iwamura, J. Am. Chem. Soc., 86, 2095(1964).
れる ${ }^{9}$ 。 $\mathrm{Co}_{2}(\mathrm{CO})_{8}$ 触媒を用いたコハク酸合成は水の存在下で行 なわれるが，水の量を低減させるとビフランジオン〔1]が生成 する ${ }^{10) 11)}$ 。[1]は 2 分子のアセチレンと 4 分子の $\mathrm{CO}$ からなる興 味ある化合物である。

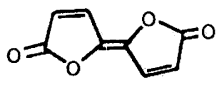

$[\underline{1}]$

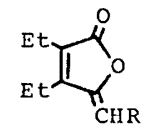

[2]

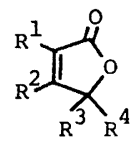

[]ㅜ
五員環不飽和ラクトンの合成にアセチンンのカルボニル化を用 いた例がいくつか知られている。量論的な反応であるが $\mathrm{Ni}(\mathrm{CO})_{4}$ とアセチレン, 酸ハロゲン化物 $\left(\mathrm{R}^{3} \mathrm{COX}\right)$ から 5-アルキル-2$(5 H)->ラ ノ ン[3 a]\left(\mathrm{R}^{1}=\mathrm{R}^{2}=\mathrm{R}^{4}=\mathrm{H}\right)$ が得られる ${ }^{12) 13)}$ 。また， $\mathrm{NaCo}(\mathrm{CO})_{4}$ と塩基の存在下，3-ヘキシンとアルキルハロゲン化

8) R.F. Heck, J. Am. Chem. Soc., 94, 2712(1972).

9) P. Pino, G. Braca, G. Sbrana, A. Cuccuru, Chem. Ind. (London), 1968, 1732.

10) J. S. Sauer, R. D. Cramer, V. A. Engelhardt, T. A. Ford, H. E. Holmquist, B. W. Houk, J. Am. Chem. Soc., 81, 3677(1959).

11) G. Albanesi, M. Tovaglieri, Chim. Ind.(Milan), 41 , 189(1959).

12) L. Cassar, G. P. Chiusoli, Tetrahedron Lett., 1966, 2805.

13) L. Cassar, G. P. Chiusoli, M. Foa, Chim. Ind. (Milan), 50, 515(1968). 
物 $\left(\mathrm{RCH}_{2} \mathrm{X}\right), \mathrm{CO}$ から [2]が生成する ${ }^{14)}$ 。この反応は電子求引 性置換基（ $\mathrm{R}$ ) をもつもののみに限定され，你煤的にはあまり進 行しない。しかし，相間移動触媒の存在下では触媒的に進行し， フェニルアセチレンとヨウ化メチル, $\mathrm{CO}$, 水から $[3 \mathrm{~b}]\left(\mathrm{R}^{1}=\mathrm{Ph}\right.$, $\left.\mathrm{R}^{2}=\mathrm{H}, \mathrm{R}^{3}=\mathrm{CH}_{3}, \mathrm{R}^{4}=\mathrm{OH}\right)$ が生成する ${ }^{15)}$ 。また, エタノール 中, $\mathrm{PdCl}_{2}$ を触媒とするとジフェニルアセチレンと $\mathrm{CO}$ から [3 c $]$ $\left(\mathrm{R}^{1}=\mathrm{R}^{2}=\mathrm{Ph}, \mathrm{R}^{3}=\mathrm{R}^{4}=\mathrm{H}\right)$ が得られている ${ }^{16) 。}$

著者らはさきに, $\mathrm{Rh}_{4}(\mathrm{CO})_{12}$ や $\mathrm{Rh}_{6}(\mathrm{CO})_{16}$ を触媒とした等香 雉化合物之種々の不飽和化合物の反応について報告した ${ }^{17) ~ 21) 。 ~}$

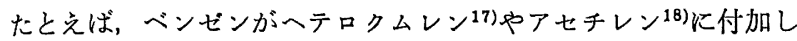
た。また，ベンゼンとェチレンの反応ではスチレンが直接得られ る19)。いずれも触媒により芳香族 $\mathrm{sp}^{2}-\mathrm{CH}$ 結合が活性化され，不 飽和化合物と相互作用した結果に基づくものと考えられる。この 反応系では一酸化炭絜の加圧が不可欠である。これは触媒活性 種，とくにはロジウムクラスター構造の保持に重要な役割を果た すむのと推察される。ところで, 最近 Laine らにより $\mathrm{Rh}_{6}(\mathrm{CO})_{16}$ を触媒とした重水によるトリェチルアミンの $\beta$-水素の選択的な $\mathrm{H}-\mathrm{D}$ 交換反応が見いだされた ${ }^{22)}$ これは $\mathrm{sp}^{3}-\mathrm{CH}$ の活性比例で あり，反応は著者らの系と同様に $\mathrm{CO}$ 加圧下で行なわれている。

著者らは Laine らの結果に注目し，さきの $\mathrm{sp}^{2}-\mathrm{CH}$ の活性化 に基づく有機合成反応をさらに $\mathrm{sp}^{3}-\mathrm{CH}$ に拡張すべく，トリエチ ルアミンとジフェニルアセチレン $[4 \mathrm{a}]$ の反応について検討した。 当初, トリエチルアミンと [4a]の付加生成物を期待したが，実 際には複雑な混合物を生成し，その中に 5-エチリデン-3,4-ジフ ェニル-2 $(5 H)$-フラノン[5]が少量含まれることを確認した。 ここでェチレンを共存させると [5]還元体である5-エチル-3,

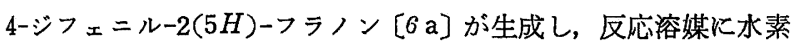
供与性溶媒を用いると $[6 \mathrm{a}]$ の収率がいちじるしく向上すること を見いだした ${ }^{23)}$ 。本報ではこれら五員環不飽和ラクトンの生成に ついて詳述する。

\section{2 結果および考察}

2.1 トリエチルアミン中でのジフェニルアセチレンのカルボ ニル化

$\mathrm{CO}$ 加圧下でジフェニルアセキレン $[4 \mathrm{a}]$ と触媒量の $\mathrm{Rh}_{4}(\mathrm{CO})_{12}$ をベンゼン中で加熱するとトリフェニルェチレン［7]と $2,3-シ$ フェニル-1-インデノン [8]が生成する ${ }^{18)}$ 。いずれるベンゼンが 反応に関与した生成物である。[7]はベンゼン $\mathrm{CH}$ 結合が触媒 に酸化的付加して開裂し，〔4a〕に付加した生成物である。【8〕 では 2 個の $\mathrm{CH}$ 結合が開裂している。

14) R. F. Heck, J. Am. Chem. Soc., 86, 2819(1964).

15) H. Alper, J. K. Currie, H. des Abbayes, J. Chem. Soc., Chem. Commun., 1978, 311.

16) J. Tsuji, T. Nogi, J. Am. Chem. Soc., 88, 1289(1966).

17) P. Hong, H. Yamazaki, K. Sonogashira, N. Hagihara, Chem. Lett., 1978, 535.

18) P. Hong, B-R. Cho, H. Yamazaki, ibid., 1979, 339.

19) P. Hong, H. Yamazaki, ibid., 1979, 1335.

20) T. Mise, P. Hong, H. Yamazaki, ibid., 1980, 439.

21) P. Hong, B-R. Cho, H. Yamazaki, ibid., 1980, 507.

22) R. M. Laine, D. W. Thomas, L. W. Cary, S. E. Buttrill, J. Am. Chem. Soc., 100, 6527(1978).

23) P. Hong, T. Mise, H. Yamazaki, Chem. Lett., 1981, 989.

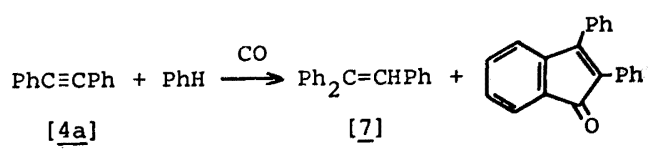

[]

一方，Laine らが行なった CO 加圧下での重水によるトリェチ ルアミンの $\mathrm{H}-\mathrm{D}$ 交换はCO変性反応を利用したものであるが，反 応過程ではトリエチルアミンの $\alpha-$ 拉よび $\beta-\mathrm{CH}$ がロジウムク ラスター三角面に酸化的付加した中間体が考光られている ${ }^{22)}$ 。著 者らはこのような反応から類推し、トリェチルアミンがペンゼン と同様にアセチレンに付加するものと考光, $\mathrm{Rh}_{4}(\mathrm{CO})_{12}$ を触媒と した CO 加圧下でのトリェチルアミンと $[4 \mathrm{a}]$ の反応を行なった。

$\mathrm{CO}$ 加压下 $\left(30 \mathrm{~kg} / \mathrm{cm}^{2}\right)$ で [4 a ] と触媒量の $\mathrm{Rh}_{4}(\mathrm{CO})_{12}$ をトリ エボルアミン中, $220^{\circ} \mathrm{C}$ で 6 時間加熱した。得られた反応混合物 をカラムクロマトグラフィーにより分離し， $2,3,4,5$-テトラフェ ニル-2, 3-シクロペンテン-1-オン [9] (35\%)，スチルベン [10] (21\%) および 1-ベンジリデン-2,3-ジフェニルインデン [11] (12 \%) とともに $\mathrm{C}_{18} \mathrm{H}_{14} \mathrm{O}_{2}$ の組成をすつ黄色化合物 [5] (5\%) を得 た。〔9]，[10]特よび [11]はそれぞれ [4a]のカルボニル化生 成物, 還元体, 二量体である ${ }^{18)}$ 。

[5]の IR スペクトルは 1754 と $1672 \mathrm{~cm}^{-1}$ にそれぞれ $\nu_{\mathrm{C}=0}$ と $\nu_{C=0}$ に基づく吸収を示し, NMR スペクトルはフェニル基に よるシグナル以外に $\delta 1.29\left(\mathrm{~d}, 3 \mathrm{H}, \mathrm{CH}_{8}\right)$ と $5.21(\mathrm{q}, 1 \mathrm{H}$, $=\mathrm{CH}-)$ に吸収があり, ェチリデン基 $\left(=\mathrm{CHCH}_{8}\right)$ の存在を示した。 これらのスペクトルならびに水素化により後述の [6 a $]$ となる事 実から，[5]は5-エチリデン-2,3-ジフェニル-2(5H)-フラノン であると結論した。な拉，反応混合物の GC-MS からは期待した トリエチルアミンと $[4 \mathrm{a}]$ の $1: 1$ 付加体の生成は認められなか った。

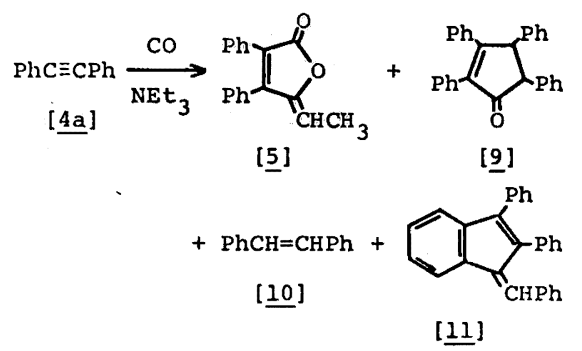

\section{2 エチレン共存下におけるアセチレンのカルボニル化}

ブテノリド構造は天然物化合物中にしばしば認められ，その中 に生理活性を示すものも少なくない。そのために，その合成法の 開発に多くの関心が寄せられている24)25)。[5]もブテノリドの一 種であるが，反応(2)における収率は非常に低い。[5]は [4a], 2 分子の CO およびェチリデン基からなり，エチリデン基はトリ エチルアミンの N-C 結合の開裂により生じたものと思われる。 エチレンがエチリデン基と同組成であり，オスミウムクラスター 上で，酸化的付加 ${ }^{26) 27)}$ やエチリジン基 (三C- $\left.\mathrm{CH}_{3}\right)$ への変換 ${ }^{28)}$ が

24) Y.S. Rao, Chem. Rev., 76, 625(1976).

25）山林 忠, 有合化，39，25(1981).

26) A. J. Deeming, S. Hasso, M. Underhill, J. Chem. Soc., Dalton Trans., 1975, 1614.

27) J. B. Keister, J. R. Shapley, J. Organomet. Chem., 85, C 29(1975). 
認められることから，反応系へのその添加は〔5]の収率を向上 させるものと考光、反応 ( 2$)$ にェチレン $\left(20 \mathrm{~kg} / \mathrm{cm}^{2}\right)$ を加光，反 応を行なった。その結果は〔5]よりもむしろその還元体である 5-エチルー3,4-ジフェニル-2(5H) フラノン $[6 \mathrm{a}]$ を $16 \%$ 収率で 与えることを示した。

$$
\mathrm{PhC} \equiv \mathrm{CPh}+\mathrm{C}_{2} \mathrm{H}_{4}+2 \mathrm{CO}+\left(\mathrm{H}_{2}\right) \rightarrow \underset{\text { [a] }}{\text { (6a }]}
$$

[6 a] は無色結晶で, その IR は 1732 と $1642 \mathrm{~cm}^{-1}$ に $\nu_{\mathrm{O}-0}$ と $\nu_{\mathrm{C}=\mathrm{O}}$ の吸収を示す。また, NMR は $\delta 0.90\left(\mathrm{t}, 3 \mathrm{H}, \mathrm{CH}_{3}\right)$, $1.56\left(\mathrm{~m}, 1 \mathrm{H}, \mathrm{CH}_{\mathrm{a}} \mathrm{H}_{\mathrm{b}}\right), 1.89\left(\mathrm{~m}, 1 \mathrm{H}, \mathrm{CH}_{\mathrm{a}} \mathrm{H}_{\mathrm{b}}\right), 5.41(\mathrm{dd}, 1 \mathrm{H}$, $-\mathrm{C} H-)$ に吸収を示す。 $\delta 1.56$ と 1.89 K現われた多重線はラ クトン環内 5-位の不斉炭索により非等洒になったメチレン基 $\left(-\mathrm{CH}_{\mathrm{a}} \mathrm{H}_{\mathrm{b}}-\right)$ によるもので, メチレン水素同士ならびに隣接する メチル基やメチン基とのカップリングにより䙓雑になったものと 思われる。また， $\delta 5.41$ の二重の二重線は隣接メチレン基の 2 個の水素と異なった結合常数 $\left(J \mathrm{HH}_{\mathrm{a}}=7 \mathrm{~Hz}, J \mathrm{HH}_{\mathrm{b}}=4 \mathrm{~Hz}\right)$ でカ ップリンクしたためと考えられる。[6a]は [5]の水素化を短時 間行なっても得られる。長時間の水素化では $[6 \mathrm{a}]$ の還元む起こ ク，〔12]が生成した。これらの結果は $[6 \mathrm{a}]$ の構造の妥当性を示 するのである。

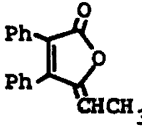

[]
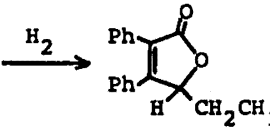

[므]
[12]

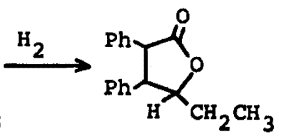

トリエチルフミンにかえてアセトンやTHFを溶媒に用いても， 同程度の収率で $[6 \mathrm{a}]$ が生成した。このさいに，[9]，[10]，[11] ととむに 1, 2,3,4-テトラフェニル-1,3-シクロへキサジェン [13] の生成が認められた。〔13]は [4a]とェチレンの共三量体であ る。反応式 ( 3 ) K示したように [6 a ] の生成には 1 分子の水素が 必要である。これは溶媒またはガス中の水から，すなわち，その CO 变性反応により供給されるるのと思われた。そこで，アセト ン $(50 \mathrm{ml})$ に水を $5 \mathrm{~m} l$ および $10 \mathrm{ml}$ 加光, 反応を行なったとこ ろ，〔6 a〕 の収率が 44，49\% といちじるしく向上することを見 いたした。また，フルコール類を溶媒とすると収率がさらに向上 することがわかった。たとえば，エタノールや1ー抽よ゙ 2-プロ ハノール中での反応では，それぞれ 60，53，61\% の収察であっ た。また，ィタノール中では収率が少し低下し，30\%であった。 これらの結果を表 1 と示した。な扰，これら水䋕供与侳溶㷊を用 いず，水秦 $\left(5 \mathrm{~kg} / \mathrm{cm}^{2}\right)$ を加生した系では [6a] は法とんど生成 しなかった。

アルコール中では，脱水索反応により水素が供給され，脱水素 生成物として，エタノールや 1-ブロパノールの場合にはアセト アルデヒド=ジェチル=アセタールやブロピオンアルデヒド=ジプ ロピル=アセタールの生成がそれぞれ確認された。また，2-プロ パールではアセトンが脱水菜生成物であった。含水アセトンや アルコール中での反応では顕著な圧力減少が涩められた。これは

28) S. C. Brown, J. Evans, J. Organomet. Chem., 194, C 53 (1980).
Table 1 Formation of furanone $[6 \mathrm{a}]$ in several

\begin{tabular}{|c|c|}
\hline Solvent & Yield of $[6 \mathrm{a}](\%)^{b)}$ \\
\hline$\left(\mathrm{C}_{2} \mathrm{H}_{5}\right)_{3} \mathrm{~N}$ & 16 \\
\hline $\mathrm{THF}$ & 15 \\
\hline$\left(\mathrm{CH}_{8}\right)_{2} \mathrm{CO}$ & 14 \\
\hline$\left(\mathrm{CH}_{3}\right)_{2} \mathrm{CO} / \mathrm{H}_{2} \mathrm{O}(10 / 1)$ & 44 \\
\hline$(5 / 1)$ & 49 \\
\hline $\mathrm{CH}_{9} \mathrm{OH}$ & 30 \\
\hline $\mathrm{C}_{2} \mathrm{H}_{5} \mathrm{OH}$ & 60 \\
\hline$n-\mathrm{C}_{3} \mathrm{H}_{5} \mathrm{OH}$ & 53 \\
\hline$i-\mathrm{C}_{8} \mathrm{H}_{5} \mathrm{OH}$ & 61 \\
\hline
\end{tabular}
proton donors ${ }^{a)}$

a) Operating conditions: $[4 \mathrm{a}] ; 10 \mathrm{mmol}, \mathrm{Rh}_{4}(\mathrm{CO})_{12}$; $0.025 \mathrm{mmol}$, Solvent ; $50 \mathrm{ml}, \mathrm{CO} ; 30 \mathrm{~kg} / \mathrm{cm}^{2}, \mathrm{C}_{2} \mathrm{H}_{4}$; $20 \mathrm{~kg} / \mathrm{cm}^{2}$, Temp. ; $220^{\circ} \mathrm{C}$, Time ; $6 \mathrm{~h}$.

$b)$ The yields were based on $[4 \mathrm{a}]$ used and were determined by GC.

Table 2 The activities of several rhodium catalysts in the carbonylation of $[4 \mathrm{a}]^{a}$ )

\begin{tabular}{lcc} 
Catalyst & $\begin{array}{c}\text { Temp. } \\
\left({ }^{\circ} \mathrm{C}\right)\end{array}$ & $\begin{array}{c}\text { Yield of }[6 \mathrm{a}] \\
(\%)^{b)}\end{array}$ \\
\hline $\mathrm{Rh}_{4}(\mathrm{CO})_{12}[14 \mathrm{a}]$ & 220 & 60 \\
& 150 & 67 \\
$\mathrm{Rh}_{6}(\mathrm{CO})_{16}[14 \mathrm{~b}]$ & 150 & 59 \\
$\mathrm{RhCl}(\mathrm{CO})\left(\mathrm{PPh}_{8}\right)_{2}[14 \mathrm{c}]$ & 220 & 48 \\
& 150 & $30^{c)}$ \\
$\mathrm{RhCl}^{\mathrm{c}}\left(\mathrm{PPh}_{8}\right)_{8}[14 \mathrm{~d}]$ & 220 & $27^{d)}$ \\
$\mathrm{RhCl}_{3} \cdot 3 \mathrm{H}_{2} \mathrm{O}[14 \mathrm{e}]$ & 220 & 41 \\
$\mathrm{Rh}_{2} \mathrm{O}_{8}[14 \mathrm{f}]$ & 220 & 58 \\
& 150 & 26 \\
$5 \% \mathrm{Rh} / \mathrm{C}[14 \mathrm{~g}]$ & 220 & 49
\end{tabular}

a) Operating conditions : $[4 \mathrm{a}] ; 10 \mathrm{mmol}$, Catalyst ; 0.1 $\mathrm{mg}$ atom, EtOH $; 50 \mathrm{ml}, \mathrm{CO} ; 30 \mathrm{~kg} / \mathrm{cm}^{2}, \mathrm{C}_{2} \mathrm{H}_{4} ; 20$ $\mathrm{kg} / \mathrm{cm}^{2}$, Time ; $6 \mathrm{~h}$.

$b$ ) The yields were based on [4a] used and were determined by GC.

c) The conversion of $[1 \mathrm{a}]$ was $40 \%$

d) The conversion of $[4 \mathrm{a}]$ was $67 \%$.

後で述べるエチレンのヒドロカルボニル化に基づくジェチルケト ン生成によるためである。

触媒としては $\mathrm{Rh}_{4}(\mathrm{CO})_{12}[14 \mathrm{a}]$ 以外飞, $\mathrm{Rh}_{6}(\mathrm{CO})_{16}[14 \mathrm{~b}]$ p $\mathrm{RhCl}(\mathrm{CO})\left(\mathrm{PPh}_{8}\right)_{2}[14 \mathrm{c}], \quad \mathrm{RhCl}\left(\mathrm{PPh}_{8}\right)_{3}[14 \mathrm{~d}], \mathrm{RhCl}_{8} \cdot 3 \mathrm{H}_{2} \mathrm{O}$ [14 e], $\mathrm{Rh}_{2} \mathrm{O}_{3}[14 \mathrm{f}], 5 \% \mathrm{Rh}-\mathrm{C}[14 \mathrm{~g}]$ のようなロジウム䤮体や 塩類も使用できるが，触媒活性には差玨が認められた。

表 2 に示したように, 反応温度 $220^{\circ} \mathrm{C}$ に拈いては $[14 \mathrm{~d}]([6 \mathrm{a}]$ ；27\% 収率）を除いて倔媒活性（40～60\%) に大きな差は認めら れない。しかし，反応盕度を $150^{\circ} \mathrm{C}$ に低下させると，〔14 a の活 性 $(67 \%)$ は変わら与゙, 〔14b] (59\%) むそれと同様の活性を示す が, 〔14 c] (30\%) や[14f] (26\%) ではいちじるしく活性が低下 した。ここで,〔14f〕を触媒とした場合にはエタノール自身がカ ルボニル化に関与した後述の [15] (19\%) と〔16] (22\%) が生成 した。

これらの結果は [14a]や[14b]のようなロジウムクラスター 化合物が你媒としてすぐれていることを示与。ロジウム化合物が 一般に CO 加压下, 高温で $\mathrm{Rh}_{0}(\mathrm{CO})_{10}$ になりやすく ${ }^{20)}$, トリフ

29) P. Chini, S. Martinengo, Inorg. Chim. Acta, 3, 21 (1969). 
Table 3 Influence of the reaction temperature in the carbonylation of $[1 \mathrm{a}]$ in the presence of ethylene and ethanol ${ }^{a}$ )

\begin{tabular}{cccccc}
$\begin{array}{c}\text { Temp. } \\
\left({ }^{\circ} \mathrm{C}\right)\end{array}$ & $\begin{array}{c}{[6 \mathrm{a}]} \\
\left.(\%)^{b}\right)\end{array}$ & $\begin{array}{c}{[15]} \\
(\%)^{b)}\end{array}$ & $\begin{array}{c}{[16]} \\
(\%)^{b)}\end{array}$ & $\begin{array}{c}\mathrm{CH}_{8} \mathrm{CH}\left(\mathrm{OCH}_{2} \mathrm{CH}_{8}\right)_{2} \\
(\mathrm{mmol})\end{array}$ & $\begin{array}{c}\left(\mathrm{CH}_{8} \mathrm{CH}_{2}\right)_{2} \mathrm{CO} \\
(\mathrm{mmol})\end{array}$ \\
\hline 220 & 60 & - & - & 49.4 & 56.6 \\
180 & 73 & - & - & 25.5 & 41.7 \\
150 & 67 & - & 3 & 4.6 & 14.4 \\
125 & 31 & 4 & 11 & 0.5 & 0.2 \\
$100^{\circ)}$ & 10 & 13 & 10 & - & -
\end{tabular}

a) Operating conditions : [4 a ]; $10 \mathrm{mmol}, \mathrm{Rh}_{4}(\mathrm{CO})_{12} ; 0.025 \mathrm{mmol}, \mathrm{CO} ; 30 \mathrm{~kg} / \mathrm{cm}^{2}$, $\mathrm{C}_{2} \mathrm{H}_{4} ; 20 \mathrm{~kg} / \mathrm{cm}^{2}$, EtOH ; $50 \mathrm{ml}$, Time ; $6 \mathrm{~h}$.

b) The yields were based on $[4 \mathrm{a}]$ used and were determined by GC and NMR.

c) The conversion of $[4 \mathrm{a}]$ was $71 \%$.

ェニルホスフィンが存在するとロジウムカルボニルのクラスター 化が妨げられる ${ }^{80)}$ といら事実を合わせ考えると触媒活珄種がクラ スター構造を有する可能性を示すものかも知れない。なお，触媒 として $\mathrm{Ir}_{4}(\mathrm{CO})_{12}, \operatorname{IrCl}(\mathrm{CO})\left(\mathrm{PPh}_{3}\right)_{2}, \mathrm{Ru}_{8}(\mathrm{CO})_{12}, \mathrm{CoCl}\left(\mathrm{PPh}_{8}\right)_{8}$, $\mathrm{PdCl}_{2}$ なども使用したが，いずれも [6 a]を与えなかった。をた， $\mathrm{Co}_{2}(\mathrm{CO})_{8}$ を用いたときにはコバルト原子あたり等モルの [6a が生成した。

2-ブチン $[4 \mathrm{~b}]$ も [4a] と同様に反応し，5-エチル-3,4-ジメチ ル-2 $(5 \mathrm{H})$-フラノン $[6 \mathrm{~b}]$ を $58 \%$ 収率で与兄た。また 1 オ ルプロピン [4c]からは 5-エチル-3-メチル-4-フェニル-2(5H)フラノン $[6 \mathrm{c}]$ と 5-エチル-3-フェニル-4-メチル-2(5H)-フラ ข[6 d]がそれぞれ 48，4\% の収率で得られ，反応が比較的高い 位置選択性で進むことを示した。 $[6 \mathrm{c}]$ と $[6 \mathrm{~d}]$ の桠造は NMR に打ける環上のメチル基とメチン基間の遠距離カップリンクの有 無により決定した。すなわち，〔6 c] のメチル基にはカップリン グが楒められず，一重線であるが，〔6 d 〕では $2 \mathrm{~Hz}$ の結合定数 をもつ二重線であった。

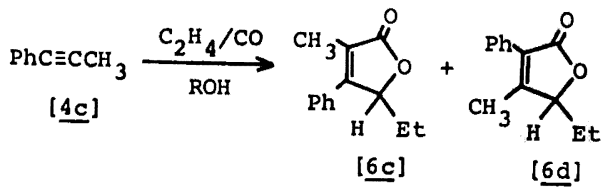

一方，フェニルアセチレンや 1-ヘキシンのような末端アセチ レンは相当するラクトンを与えなかった。これはアセチレン水素 が触媒と反応するためと考えられる。また,フェニルフセチレン カルボン酸メチルでは三量体と,〔9]と同様なンクロペンテノン 誘導体を与え, ラクトンは生成しなかった。

前に述べたように，反応溶媒としてはアルコールが珢道であ り［6]の生成に必要な水素を脱水素反応により供給する。しか し, 実際には, 脱水素反応は必要以上に起こり，エチレンのヒド ロカルボニル化による多量のジェチルケトンの生成豆)をむたらし

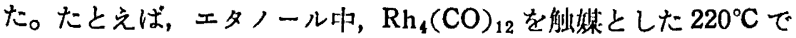
の反応では，ジェルケトンとアセトアルデヒド=ジェチル=フセ タールがそれぞれ $56.6 \mathrm{mmol}, 49.4 \mathrm{mmol}$ 生成した。アナター ルは脱水素生成物であるアセトアルデヒドとェタノールの縮合生 成物である。

30) R. Whyman, J.Chem. Soc., Dalton Trans., 1972, 1375.

31) Y. Iwashita, M. Sakuraba, Tetrahederon Lett., 1971, 2409.

$$
\begin{aligned}
& \mathrm{CH}_{8} \mathrm{CH}_{2} \mathrm{OH} \longrightarrow \mathrm{CH}_{8} \mathrm{CHO}+\mathrm{H}_{2} \\
& \mathrm{CH}_{8} \mathrm{CHO}+2 \mathrm{CH}_{8} \mathrm{CH}_{2} \mathrm{OH} \longrightarrow \mathrm{CH}_{3} \mathrm{CH}\left(\mathrm{OCH}_{2} \mathrm{CH}_{3}\right)_{2} \\
& 2 \mathrm{CH}_{2}=\mathrm{CH}_{2}+\mathrm{CO}+\mathrm{H}_{2} \longrightarrow\left(\mathrm{CH}_{8} \mathrm{CH}_{2}\right)_{2} \mathrm{CO}
\end{aligned}
$$

フセタールとケトンの生成を抑制するため，反応温度の影䨋を 調べた。その結果を表 3 に示した。反応温度を $180^{\circ} \mathrm{C}$ にすると [6a]はもっともよい収率 (73\%)を示すが，相当量のアセタール (25. $5 \mathrm{mmol})$ とケトン (41.7 mmol) の生成をまたともなった。 さらに, $150^{\circ} \mathrm{C}$ に下げると $[6 \mathrm{a}]$ は $67 \%$ 收率で, アセタール (4.6 mmol) 扰よびヶトン $(14.4 \mathrm{mmol})$ の副生はかなり抑之ら. れることがわかった。また， $125^{\circ} \mathrm{C}$ 以下ではこれら副生成物はほ とんど認められないが，[6a] の収率はいちしるしく低下し， エ タノール自身がェチレンにかわってカルボニル化に関与した 5エトキシ-3, 4-ジフェニル-2(5H)-フラノン[15]と 3-(エトキシ カルボニル)-2-フェニル-1-インダノン [16] の生成をともなっ

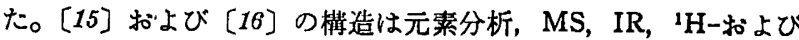
${ }^{18} \mathrm{C}-\mathrm{NMR}$ をもとにして決定した。な拉，〔15]はエタノール中， ロジウム触媒に無機塩基を添加し，〔4 a〕をカルボニル化すると 高収率で得ることができる ${ }^{22) 。 ~}$

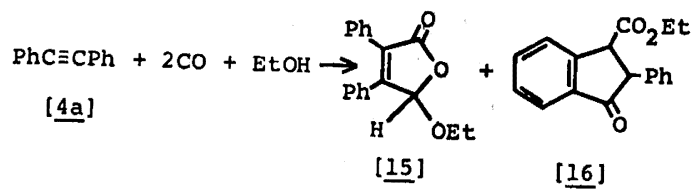

\subsection{5 -エチル-2(5H)-フラノン [6]の生成機栱}

アシル錯体， $\mathrm{R}^{1} \mathrm{COCo}(\mathrm{CO})$ 、とアセチレン $\left(\mathrm{R}^{2} \mathrm{C} \equiv \mathrm{CR}^{2}\right)$ の反応 により $\eta^{3}$ ーラクトニル鍇体 [17]が生成する8)。[17]はアシルーב バト絬合にアセチレン, $\mathrm{CO}$ が順次插入し，分子内閉聚して 生成すると考光られている。同様な反応は $\left(\eta^{5}-\mathrm{C}_{5} \mathrm{H}_{5}\right) \mathrm{M}(\mathrm{CO})_{8}$ $\left(\mathrm{COCF}_{8}\right)(\mathrm{M}=\mathrm{Mo}, \mathrm{W})$ とアセチレンの反応でも認められてお り, アセチレンの挿入により生じるビニルケトン錯体も単離され ている ${ }^{33)}$ 。一方, $\mathrm{Rh}_{4}(\mathrm{CO})_{12}$ は水存在下で, エチレン, $\mathrm{CO}$ と反 応してアシル錯体， $\left[\mathrm{Rh}_{0}(\mathrm{CO})_{15}(\mathrm{COEt})\right]^{-}[18]$ を与える ${ }^{34)}$ 。 [18]

32) T. Mise, P. Hong, H. Yamazaki, Chem. Lett., 1981, 993.

33) M. Green, J. Z. Nyathi, C. Scott, F. G. A. Stone, A. J. Welch, P. Woodward, J. Chem. Soc., Dalton Trans., 1978, 1067.

34) P. Chini, S. Martinengo, G. Carlaschelli, J. Chem. Soc., Chem. Commun., 1972, 709. 
はまず生成するヒドリド錯体にェチレン，CO が捜入したものと 考えられる。

$$
\text { [1] }
$$

これらの事垁から[6]の生成には図式1に示したような経路が 考えられる。水素供与体である水やアルコールと触媒からまずヒ ドリド錯体 [19]が生成し，これにエチレン，COが反応してアシ ル中間体 [20]となる。[20] のアシル-Rh 結合にアセチレン, CO が䐓次挿入し，[21] ならびに [22]となり，[22]の分子内 環化によりラクトニル錯体 [23]が生成する。[23]はアルコール により還元され，[6]を生成し，[19]を再生する。ここで生じ たフルデヒドはアルコールと反応してアセタールとなる。また， ジェチルケトンは [20]へのエチレンの反応により生成するもの と考えられる。

1-フェニルプロピン $[4 \mathrm{c}]$ のカルボニル化では位置異性体 $[6 \mathrm{c}]$ を主生成物として与え, ベンビンの [4 c ] への付加による $\alpha$-メ チルスチルベンの生成 ${ }^{18)}$ とは逆の位置選択性を示した。これは次 式に示すようなアシル中間体とフェニル中間体の分極構造の違い により説明できる。すなわち，正電荷をるつアシル基は [4 c $]$ の 電子密度の高い1-位を, 負電荷をるつフェニル基は逆に電子密 度の低い2-位を攻撃するためめであろう。

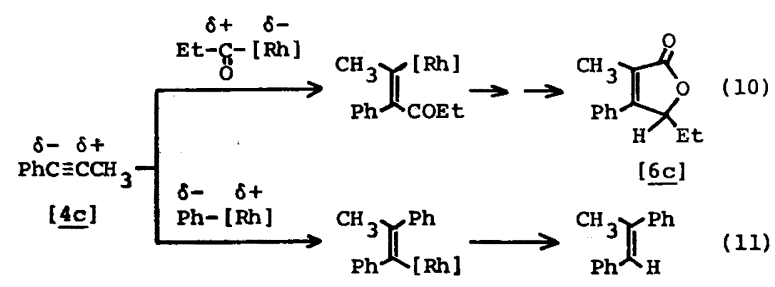

反応式(9)に示したように，低温ではェタノールがエチレンに かわってカルボニル化に関与し，[15]や[16]を与えた。これら はエタノールの配位 $\mathrm{CO}$ への求核的な攻整により生じるェトキシ カルボニル中間体 [24]を経て生成するすのと考元られる。〔6] の生成においても考えた[20]の反応と同様に，[24]へのアセチ レン, $\mathrm{CO}$ の挿入，分子内環化過程を考慮すれば，[15]の生成が

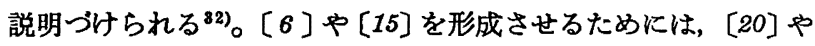
[24] のフセチレンへの反応はシス付加でなければならない。し かし, シス付加体 [25]から[16]の形成は困難であり, むしろ, トランス付加体 [26]からの生成経路を考えるのが妥当であろら。 図式 2 にその可能な生成機構を示した。なお，のーアルケニル錯体 のシスートランス異性化例が報告されている ${ }^{85)}$ 。

\section{3 実験}

IR スペクトルは島津 IR-27 G 型をたは日本分光 $\mathrm{A}-202$ 型を

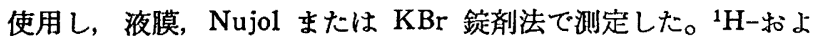
び ${ }^{18} \mathrm{C}-\mathrm{NMR}$ スペクトルはV Varian HA-100 B 型, 日本電子 JNM-FX-100 型をそれぞれ使用し，クロロホルム- $d$ 中, TMS

35) D. L. Reger, P. J. McElligott, J. Am. Chem. Soc., 102, 5923 (1980).

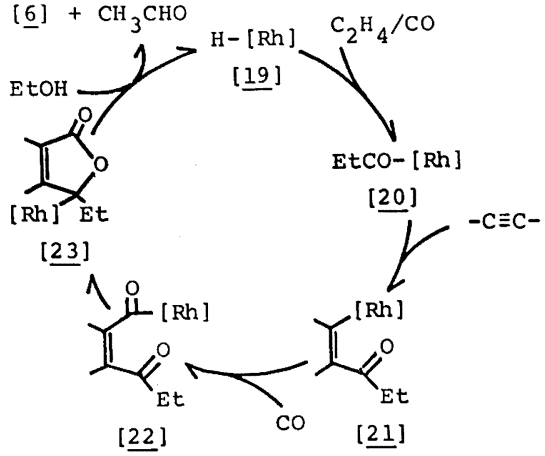

Scheme 1
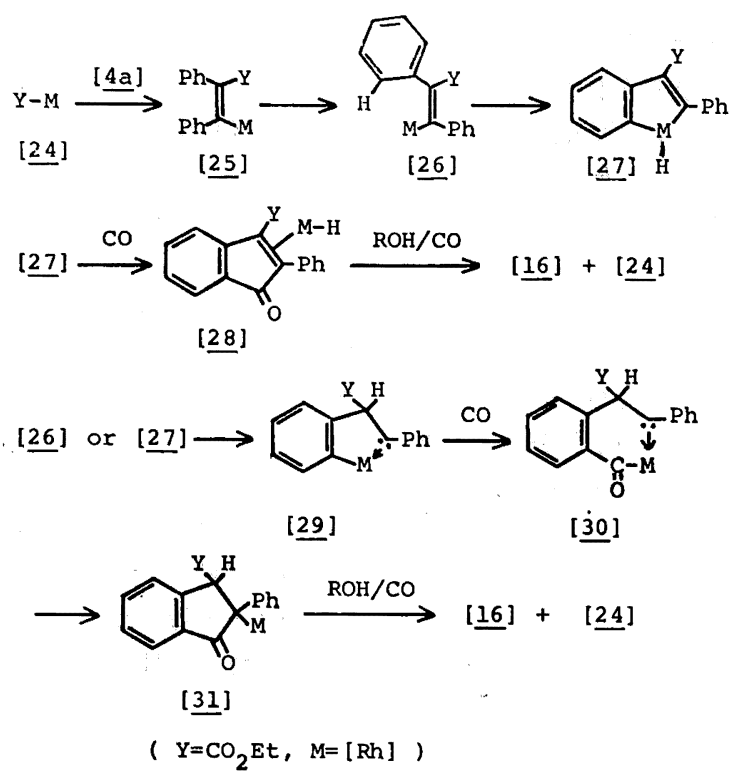

Scheme 2

を内部標準として測定した。ガスクロマトグラフィー（GC）は島 津 $\mathrm{GC}-4 \mathrm{C}$ 型 ( $\mathrm{He}$ ガス) または GC-4 CM 型 ( $\mathrm{N}_{2}$ ガス) で測 定した。GC-MS は日立 RMU-6 MG 型で測定した。融点は三 田村理研微量融点測定装置を用いて測定した未補正值である。カ ラムクロマトグラフィーではシリカゲル（Wako C-200）を使用 した。

\section{1 試 薬}

ジフェニルアセチレン $[4 \mathrm{a}]^{36)}$ および 2-ブチン $[4 \mathrm{~b}]^{37)}$ は文 献記載の方法により合成した。1ーフェニルプロピン〔4 c 〕は市肘 品を用いた。触媒に用いた $\mathrm{Rh}_{4}(\mathrm{CO})_{12}{ }^{38)}, \mathrm{RhCl}(\mathrm{CO})\left(\mathrm{PPh}_{3}\right)_{2}{ }^{39)}$, および $\mathrm{RhCl}\left(\mathrm{PPh}_{3}\right)_{8}{ }^{40)}$ はそれぞれ文献記載の方法により合成し,

36) A. C. Cope, D. S. Smith, R. J. Cotter, "Organic Syntheses", Col. Vol. N, p.377(1963).

37) L. Brandsma, "Preparative Acetylenic Chemistry", Elsevier, Amsterdam (1971) p. 146.

38) S. Martinengo, P. Chini, G. Giordano, J. Organomet. Chem., 27, 389(1971).

39) D. Evans, J. A. Osborn, G. Wilkinson, "Inorg. Syntheses", Vol. XI, p.99(1968).

40) J. A. Osborn, G. Wilkinson, "Inorg. Syntheses", Vol. $\mathrm{X}$, p. 67(1967). 
$\mathrm{Rh}_{6}(\mathrm{CO})_{16}$ は $\mathrm{Rh}_{4}(\mathrm{CO})_{12}$ のへキサン溶液を $\mathrm{CO}$ 加圧下 $(40 \mathrm{~kg} /$ $\left.\mathrm{cm}^{2}\right), 100^{\circ} \mathrm{C}$ で加熱して合成した。その他の触媒は市販品を用い た。溶媒は特記したもの以外，市販品特級を精製せず，使用し た。

\section{2 トリエチルアミン中での $[4 \mathrm{a}]$ のカルボニル化}

内容積 $100 \mathrm{ml}$ の振とう式ステンレススチール製オートクレー ブに $[4 \mathrm{a}](1.78 \mathrm{~g}, 10 \mathrm{mmol}), \mathrm{Rh}_{4}(\mathrm{CO})_{12}(38 \mathrm{mg}, 0.05 \mathrm{mmol})$ およびトリェチルアミン $(30 \mathrm{ml})$ を加え, $\mathrm{CO}\left(30 \mathrm{~kg} / \mathrm{cm}^{2}\right)$ を充 埧し， $220^{\circ} \mathrm{C} て ゙ 6$ 時間加熱した。得られた赤褐色溶液を減圧濃縮 後, カラムクロマトグラフィー分離した。へキサンーベンゼン (3/7) で溶出する部分から黄色結晶 [5] (143 mg，5\%収率) を 得た。 $\mathrm{mp} 155 \sim 156^{\circ} \mathrm{C}$ (ベンゼンーヘキサンから再結晶)。

分析値 C $82.39 \%$, H $5.38 \%$

$\mathrm{C}_{18} \mathrm{H}_{14} \mathrm{O}_{2}$ としての

計算值 C $82.42 \%, \mathrm{H} 5.38 \%$

$\operatorname{IR}(\mathrm{KBr})\left(\mathrm{cm}^{-1}\right): 1754(>\mathrm{C}=0), \quad 1672(>\mathrm{C}=\mathrm{C}<)$

$\operatorname{NMR} \delta(\mathrm{ppm}): 1.29\left(\mathrm{~d}, 3 \mathrm{H}, \mathrm{CH}_{3}\right), 5.29(\mathrm{q}, 1 \mathrm{H},=\mathrm{CH}-)$, 7. $1 \sim 7.5(\mathrm{~m}, 10 \mathrm{H}, \mathrm{Ph})$

$\operatorname{MS}(m / e): 262\left(\mathrm{M}^{+}\right)$

また，へキサンーベンゼン (9/1)，(4/1) および (1/4) 溶出部 から [10] (376 mg, 21\%), [11] (219 mg, 12\%), [9] (672 mg, 35\%) がそれぞれ得られた。

3.3 エチレン共存下におけるアセチレンのカルボニル化

3.3.1 エタノール中での [4 a $]$ のカルボニル化

（1） $\mathrm{Rh}_{4}(\mathrm{CO})_{12}$ 触媒による反応: 内容積 $200 \mathrm{ml}$ のステンレ ススチール製オートクレープに [4 a $](1.78 \mathrm{~g}, 10 \mathrm{mmol}), \mathrm{Rh}_{4}$ $(\mathrm{CO})_{12}(19 \mathrm{mg}, 0.025 \mathrm{mmol})$ 扎よびェタノール $(50 \mathrm{ml})$ を加 え, エチレン $\left(20 \mathrm{~kg} / \mathrm{cm}^{2}\right)$ お゙よび $\mathrm{CO}\left(30 \mathrm{~kg} / \mathrm{cm}^{2}\right)$ を充媜し， $180^{\circ} \mathrm{C}$ で 6 時間加熱した。黄色反応溶液を減圧濃縮し, エタノー ル $(10 \mathrm{ml})$ で再結晶すると [6 a $](1.112 \mathrm{~g})$ が得られた。再結晶 母液のカラムクロマトグラフィー分離により，さらに $0.348 \mathrm{~g}$ の 〔6 a を得た。合計収量 $1.460 \mathrm{~g}$ (55\% 収率)。な捄，GC（カラ ム: $3 \mathrm{~mm} \times 1.5 \mathrm{~m}$, DC $5505 \%$-Celite $545 \mathrm{SKDMS}, 230^{\circ} \mathrm{C}$ ) によれば $[6 \mathrm{a}]$ の収量は $1.913 \mathrm{~g}(73 \%)$ であった。無色結晶, $\operatorname{mp~} 133 \sim 134^{\circ} \mathrm{C}$ 。

分析値 C $81.78 \%, \mathrm{H} 6.06 \%$

$\mathrm{C}_{18} \mathrm{H}_{16} \mathrm{O}_{2}$ としての

計算值 C $81.79 \%, \mathrm{H} 6.10 \%$

$\operatorname{IR}(\mathrm{KBr})\left(\mathrm{cm}^{-1}\right): 1732(>\mathrm{C}=\mathrm{O}), 1642(>\mathrm{C}=\mathrm{C}<)$

NMR $\delta(\mathrm{ppm}): 0.90\left(\mathrm{t}, J=7 \mathrm{~Hz}, 3 \mathrm{H}, \mathrm{CH}_{3}\right), 1.56(\mathrm{~m}, 1 \mathrm{H}$, $\left.-\mathrm{CH}_{\mathrm{a}} \mathrm{H}_{\mathrm{b}}-\right), 1.89\left(\mathrm{~m}, 1 \mathrm{H},-\mathrm{CH}_{\mathrm{a}} \mathrm{H}_{\mathrm{b}}-\right), 5.41\left(\mathrm{dd}, J \mathrm{HH}_{\mathrm{a}}=7 \mathrm{~Hz}\right.$, $\left.J_{\mathrm{HH}_{\mathrm{b}}}=4 \mathrm{~Hz}, 1 \mathrm{H},-\stackrel{\mathrm{C}}{\mathrm{C}} \mathrm{H}-\right), 7.27(\mathrm{~m}, 10 \mathrm{H}, \mathrm{Ph})$

$\mathrm{MS}(m / e): 264\left(\mathrm{M}^{+}\right)$

反応溶液の GC (カラム : $3 \mathrm{~mm} \times 3 \mathrm{~m}, \mathrm{PEG} 20 \mathrm{M} 15 \%$-Chromosorb $\mathrm{W}, 60^{\circ} \mathrm{C}$ ) により, アセトアルデヒド=ジェチル=アセタ ール $(3.011 \mathrm{~g})$ およびジェチルケトン $(3.584 \mathrm{~g})$ の生成を確認し た。

（2） $\mathbf{R h}_{2} \mathrm{O}_{3}$ 触媒による反応: 触媒として $\mathrm{Rh}_{2} \mathrm{O}_{3}(13 \mathrm{mg})$ を 用い，反応温度を $150^{\circ} \mathrm{C}$ とした以外は上記と同様に反応を行な い, 黄褐色溶液を得た。減圧濃縮後, カラムクロマトグラフィー により分離した。まず，ベンゼンーへキサン混合溶媒 $(100 \mathrm{ml})$ の 混合比を変えながら溶出させた。 $4 / 1$ の混合溶媒で溶出する部分
から [6a]と[15]の $1: 1$ 混合物（結晶, $697 \mathrm{mg}$ ) を得, カラ ムクロマトグラフィーと再結晶をくり返し行ない, [15]を単離し た。無色結晶, $\mathrm{mp} 137 \sim 138^{\circ} \mathrm{C}$ (ヘヘンぜンーヘキサンから再結晶)。 分析值 C $77.15 \%, \mathrm{H} 5.73 \%$

$\mathrm{C}_{18} \mathrm{H}_{18} \mathrm{O}_{8}$ としての

計算值 C $77.12 \%, \mathrm{H} 5.75 \%$

$\operatorname{IR}(\mathrm{Nujol})\left(\mathrm{cm}^{-1}\right): 1758(>\mathrm{C}=0), 1654(>\mathrm{C}=\mathrm{C}<)$.

${ }^{1} \mathrm{H}-\mathrm{NMR} \delta(\mathrm{ppm}): 1.28\left(\mathrm{t}, 3 \mathrm{H}, \mathrm{CH}_{8}\right), 3.89\left(\mathrm{~m}, 2 \mathrm{H}, \mathrm{OCH}_{2}{ }^{-}\right)$,

6. $20(\mathrm{~s}, 1 \mathrm{H}, \mathrm{CH}), 7.36(\mathrm{~m}, 10 \mathrm{H}, \mathrm{Ph})$

${ }^{13} \mathrm{C}-\mathrm{NMR} \delta(\mathrm{ppm}): 15.0\left(\mathrm{CH}_{3}\right), 65.5\left(\mathrm{OCH}_{2}\right), 101.7$ (OCHO); 128.6, 129.1, 129.3, 130.3, $153.3(\mathrm{Ph}, \mathrm{C}=\mathrm{C}), 170.5\left(\mathrm{CO}_{2}\right)$ $\operatorname{MS}(m / e): 280\left(\mathrm{M}^{+}\right)$

また, ベンゼンおよびベンゼンージクロロメタン (4/1) で溶出 部分から [16] (273 mg) を得た。無色結晶, $\mathrm{mp} 62 \sim 63^{\circ} \mathrm{C}$ (エタ ノールから再結晶)。

分析值 C $77.17 \%, \mathrm{H} 5.87 \%$

$\mathrm{C}_{18} \mathrm{H}_{18} \mathrm{O}_{8}$ としての 計算値 C $77.12 \%, \mathrm{H} 5.75 \%$

IR(Nujol) $\left(\mathrm{cm}^{-1}\right): 1728,1712(>\mathrm{C}=0)$

${ }^{1} \mathrm{H}-\mathrm{NMR} \delta(\mathrm{ppm}): 1.36\left(\mathrm{t}, 3 \mathrm{H}, \mathrm{CH}_{8}\right), 4.28\left(\mathrm{q}, 2 \mathrm{H}, \mathrm{OCH}_{2}\right)$, $4.38(\mathrm{~d}, 1 \mathrm{H}, \mathrm{CH}), 4.42(\mathrm{~d}, 1 \mathrm{H}, \mathrm{CH}), 7.1 \sim 7.9(\mathrm{~m}, 9 \mathrm{H}$, aromatic $\mathrm{H}$ )

${ }^{13} \mathrm{C}-\mathrm{NMR} \delta(\mathrm{ppm}): 14.3\left(\mathrm{CH}_{8}\right), 53.4(\mathrm{CH}), 56.6(\mathrm{CH}), 61.8$ $\left(\mathrm{OCH}_{2}\right), 124.7,126.1,127.5,128.3,129.0,135.3,135.6$, 138. 2, 149.9 (aromatic $\mathrm{H}), 171.3\left(\mathrm{CO}_{2}\right), 203.7(\mathrm{C}=\mathrm{O})$

$\mathrm{MS}(\mathrm{m} / \mathrm{e}): 280\left(\mathrm{M}^{+}\right)$

なお，（3）に示す分析によれば [6a]，[15]，[16]の収量は それぞれ $689 \mathrm{mg}(26 \%), 519 \mathrm{mg}(19 \%), 585 \mathrm{mg}(21 \%)$ であっ た。

（3） [6 a ], [15]および [16]の定贯: GC（カラム : $3 \mathrm{~mm}$ $\times 2 \mathrm{~m}$, OV $173 \%$-Chromosorb $\mathrm{W}, 200^{\circ} \mathrm{C}$ ) により, [16]の収 量と, ピークの重なる $[6 \mathrm{a}]$ と[15]の合計収量を求めた。 [6 a ] と [15]の比率は GC 分取した混合物の NMR 面積比から求め, それぞれの収量を計算した。

3.3.2 THF 中での [4 a $]$ のカルボニル化: 常法により精製 した THF $(50 \mathrm{ml})$ を溶媒とし, 反応温度を $220^{\circ} \mathrm{C}$ に設定して上 記と同様に反応を行なった。GCにより，末反応 [4 a $]$ (202 mg， $11 \%)$ と $[6 \mathrm{a}](390 \mathrm{mg}, 15 \%)$ の定量を行なった。また, 反応 混合物のカラムクロマトグラフィー分離により，[11](231 mg, $13 \%),[13](450 \mathrm{mg}, 23 \%)$ および〔9] (73 mg, 4\%) をそれ ぞれ単離した。

3.3.3〔5]および[6 a] の水素化: [5] (10 mg) のエタノ ール $(5 \mathrm{ml})$ 溶液に $5 \% \mathrm{Pd}-\mathrm{C}(50 \%$ wet, $5 \mathrm{mg})$ を加之，水素 雾囲気, 室温で 1 時間かきまぜた。触媒を汇別し，汇液を濃縮乾 固すると無色結晶が得られた。このものの IR は [6a く一致した。

[6 a] (264 mg) のエタノール $(20 \mathrm{ml})$ 溶液に $5 \% \mathrm{Pd}-\mathrm{C}(50 \%$ wet, $100 \mathrm{mg}$ ) を加光，水素雾囲気，室温で 18 時間かきまぜた。 触媒を汇別したのち，汇夜を濃縮し，残留物をベンゼンーへキサ ンから再結晶すると[12] $(120 \mathrm{mg})$ が得られた。再結母液には [12〕とともに, [6 a ] が残存することが IR により確認された。 無色結晶, $\mathrm{mp} 81 \sim 83^{\circ} \mathrm{C}$ 。 
分析值 C $81.29 \%, \mathrm{H} 6.91 \%$

$\mathrm{C}_{18} \mathrm{H}_{18} \mathrm{O}_{2}$ としての

計算値 C $81.17 \% ， \mathrm{H} 6.81 \%$

$\operatorname{IR}(\mathrm{Nujol})\left(\mathrm{cm}^{-1}\right): 1767(>\mathrm{C}=\mathrm{O})$

$\mathrm{NMR} \delta(\mathrm{ppm}): 0.92\left(\mathrm{t}, 3 \mathrm{H}, \mathrm{CH}_{3}\right), 1.58\left(\mathrm{~m}, 2 \mathrm{H}, \mathrm{CH}_{2}\right)$, 3. $86(\mathrm{dd}, 1 \mathrm{H}, \mathrm{CH}), 4.42(\mathrm{~d}, 1 \mathrm{H}, \mathrm{CH}), 4.65(\mathrm{~m}, 1 \mathrm{H}, \mathrm{CH})$, $7.12(\mathrm{~m}, 10 \mathrm{H}, \mathrm{Ph})$

$\operatorname{MS}(m / e): 266\left(\mathrm{M}^{+}\right)$

3.3.4 [4 b] のカルボニル化 : [4 b] $(1.6 \mathrm{ml}, 20 \mathrm{mmol}), \mathrm{Rh}_{4}$ $(\mathrm{CO})_{12}(19 \mathrm{mg}, 0.025 \mathrm{mmol})$ および 2 -プロパノール $(50 \mathrm{ml})$ を オートクレーブに加え，エチレン $\left(20 \mathrm{~kg} / \mathrm{cm}^{2}\right)$ および $\mathrm{CO}(30 \mathrm{~kg} /$ $\left.\mathrm{cm}^{2}\right)$ を充埧し， $180^{\circ} \mathrm{C}$ で 6 時間加熱した。 $\mathrm{GC}\left(\mathrm{OV} 17,140^{\circ} \mathrm{C}\right)$ により，〔6 b](1.622 g，58\%) の生成を確認した。[6 b により分取し，IR，NMR および GC-MS によりその構造を確 認した。無色液体。

$\operatorname{IR}$ (莅膜) $\left(\mathrm{cm}^{-1}\right): 1750(>\mathrm{C}=0), 1640(>\mathrm{C}=\mathrm{C}<)$

$\operatorname{NMR} \delta(\mathrm{ppm}): 0.91\left(\mathrm{t}, 3 \mathrm{H}, \mathrm{CH}_{3}\right), 1.55\left(\mathrm{~m}, 1 \mathrm{H}, \mathrm{CH}_{\mathrm{a}} \mathrm{H}_{\mathrm{b}}\right)$, $1.80\left(\mathrm{~m}, 3 \mathrm{H}, \mathrm{CH}_{3}\right), 1.95\left(\mathrm{~m}, 3 \mathrm{H}, \mathrm{CH}_{8}\right)$, 約 $1.9(\mathrm{~m}, 1 \mathrm{H}$,

$\left.\mathrm{CH}_{\mathrm{a}} \mathrm{H}_{\mathrm{b}}\right), 4.70$ (bs, $1 \mathrm{H}, \mathrm{CH}$ )

$\operatorname{MS}(m / e): 140\left(\mathrm{M}^{+}\right)$

3.3.5 [4 c] のカルボニル化 : [4 c ] $(2.44 \mathrm{~g}, 21 \mathrm{mmol}), \mathrm{Rh}_{4}$ $(\mathrm{CO})_{12}(19 \mathrm{mg}, 0.025 \mathrm{mmol})$ およびェタノール $(50 \mathrm{ml})$ をェチ
レン $\left(20 \mathrm{~kg} / \mathrm{cm}^{2}\right)$ と $\mathrm{CO}\left(30 \mathrm{~kg} / \mathrm{cm}^{2}\right)$ の加圧下, $220^{\circ} \mathrm{C}$ で 6 時間 加熱した。得られた黄色溶液を減圧濃縮後, カラムクロマトグラ フィーにより分離した。ベンゼンーへキサン（3/1）からベンゼン で溶出する部分を濃縮後, エタノールで再結晶し, 無色結晶 $[6 \mathrm{c}]$ $(1.595 \mathrm{~g}, 38 \%)$ を得た。 $\mathrm{mp} 84 \sim 85^{\circ} \mathrm{C}$ 。 分析值 C $77.22 \%, \mathrm{H} 7.07 \%$ $\mathrm{C}_{13} \mathrm{H}_{14} \mathrm{O}_{2}$ としての

計算值 C $77.20 \%$, H $6.98 \%$

IR(Nujol) $\left(\mathrm{cm}^{-1}\right): 1738(>\mathrm{C}=\mathrm{O}), 1661(>\mathrm{C}=\mathrm{C}<)$

NMR $\delta(\mathrm{ppm}): 0.97\left(\mathrm{t}, 3 \mathrm{H}, \mathrm{CH}_{3}\right), 1.37\left(\mathrm{~m}, 1 \mathrm{H}, \mathrm{CH}_{\mathrm{a}} \mathrm{H}_{\mathrm{b}}\right)$, 約 $2.05\left(\mathrm{~m}, 1 \mathrm{H}, \mathrm{CH}_{\mathrm{a}} \mathbf{H}_{\mathrm{b}}\right), 2.09\left(\mathrm{~s}, 3 \mathrm{H}, \mathrm{CH}_{3}\right), 4.82(\mathrm{dd}, 1 \mathrm{H}$, $\mathrm{CH}), 7.4(\mathrm{~m}, 5 \mathrm{H}, \mathrm{Ph})$

$\operatorname{MS}(m / e): 202\left(\mathrm{M}^{+}\right)$

さきの再結母液の $\mathrm{GC}$ 分取により，[6 d $]$ と $[6 \mathrm{c}]$ の $1: 1$ 混合

物を得, その NMR から $[6 \mathrm{~d}]$ の構造を推定した。

$\mathrm{NMR} \delta(\mathrm{ppm}): 0.85\left(\mathrm{t}, 3 \mathrm{H}, \mathrm{CH}_{3}\right), 1.2 \sim 2.0\left(\mathrm{~m}, 2 \mathrm{H}, \mathrm{CH}_{2}\right)$, 2. $03\left(\mathrm{~d}, J=2 \mathrm{~Hz}, 3 \mathrm{H}, \mathrm{CH}_{3}\right), 5.32(\mathrm{~m}, 1 \mathrm{H}, \mathrm{CH}), 7.4(\mathrm{~m}$, $5 \mathrm{H}, \mathrm{Ph})$

$\operatorname{MS}(m / e): 202\left(\mathrm{M}^{+}\right)$

な拈，反応混合物の GC によれば， $[6 \mathrm{c}]$ と $[6 \mathrm{~d}]$ の収量はそれ ぞれ $2.042 \mathrm{~g}(48 \%), 0.190 \mathrm{~g}(4 \%)$ であった。

\title{
Special Articles on $\mathrm{C}_{1}$ Chemistry
}

\section{Rhodium Carbonyl-Catalyzed Carbonylation of Acetylenes in the Presence of Ethylene -Synthesis of 5-Ethyl-2(5 H)-furanones ${ }^{\dagger}-$}

\author{
Pangbu Hong*, Takaya Mise and Hiroshi YAMAZAKI \\ The Institute of Physical and Chemical Research; Hirosawa, \\ Wako-shi 351 Japan
}

The carbonylation of diphenylacetylene $[4 \mathrm{a}]$ with $\mathrm{Rh}_{4}(\mathrm{CO})_{12}$ in triethylamine gave $3,4-$ diphenyl-5-ethylidene-2 $(5 \mathrm{H})$-furanone $[5]$ in a $5 \%$ yield, in which the ethylidene group was derived from the amine. Addition of ethylene to the reaction system resulted in the formation of 3, 4-diphenyl-5-ethyl-2 $(5 H)$-furanone $[6 \mathrm{a}](16 \%)$. By using protic solvents such as alcohols and aqueous acetone, the yield of $[6 \mathrm{a}]$ was increased remarkably (Table 1). Among several rhodium carbonyl complexes and their precursors used as the catalyst (Table 2), the catalytic activities of $\mathrm{Rh}_{4}(\mathrm{CO})_{12}$ and $\mathrm{Rh}_{6}(\mathrm{CO})_{16}$ were prominent. Similarly, the carbonylation of 2butyne gave 3,4-dimethyl-5-ethyl-2(5H)-furanone $[6 \mathrm{~b}]$ in a $58 \%$ yield, and that of 1 -phenylpropyne gave 5-ethyl-3-methyl-4-phenyl-2 $(5 \mathrm{H})$-furanone $[6 \mathrm{c}]$ and 5-ethyl-4-methyl-3phenyl-2 $(5 H)$-furanone $[6 \mathrm{~d}]$ in $48 \%$ and $4 \%$ yields, respectively, indicating the reaction to be regioselective. At higher temperatures $\left(150 \sim 220^{\circ} \mathrm{C}\right)[6 \mathrm{a}]$ was mainly obtained by the carbonylation of $[4 \mathrm{a}]$ in ethanol, but at lower temperatures $\left(100 \sim 125^{\circ} \mathrm{C}\right) 3,4$-diphenyl-5-ethoxy$2(5 \mathrm{H})$-furanone [15] and 3-(ethoxycarbonyl)-2-phenylindanone [16] were obtained as byproducts, which were formed by the participation of ethanol in the carbonylation. Possible mechanisms for the formations of [6] and [16] are shown in Scheme 1 and 2.

$\dagger$ Rhodium-Catalyzed Carbonylation of Unsaturated Compounds. I. 